\title{
Assessment of Land Use Land Cover Change and Decline in Sugarcane Farming Using GIS and Remote Sensing in Mumias District, Kenya
}

\author{
Hellen Mbayaki ${ }^{1}$, Kennedy Mubea ${ }^{2}$, Charles N. Mundia ${ }^{3}$ \\ Institute of Geomatics, GIS and Remote Sensing, Dedan Kimathi University of Technology, PO Box 657-10100.Njeri, Kenya
}

\begin{abstract}
Land use/cover changes are pervasive with no clear understanding of their spatial extends, drivers and impacts to society. Land-use changes have become a key component in the current strategies for managing and monitoring the natural resources and environment changes. The purpose of this study was to assess the land covers change and decline in sugarcane farming using a three time series of Landsat satellite images of 1984, 2000 and 2015. The study was guided by the following specific objectives: to determine the characteristics of land use land cover using Landsat images. Primary data collection involved actual field visit to capture GPS points while secondary data were collected from different sources composed of different kinds such as: landsat images, population data, topographical sheets, Google earth, road and rainfall data among others. Data integration involved combining data from different sources to enable evaluate driving forces and impacts of land use/cover change.Image pre-processing included: image spatial subsetting, radiometric correction, pan sharpening and image enhancement. Image processing involved supervised classification method with maximum likelihood algorithm in determination of six classes of land use/cover. Error matrix as opposed to single data assessment was used to determine the accuracy of each classified image and found within acceptable limits. The analysed data were presented in the form of maps, tales and graphs. The findings on land use/cover image map from processed data revealed six information classes as sugarcane, maize, other vegetation, built-up, water body and bare land. Maize and sugarcane had the most significant land use/cover changes with $54 \%$ increase and $39 \%$ reduction respectively. The driving forces included population, size of land and transport infrastructure. Encroachment into other land use fields haphazardly in search of space to live, farm and work indicates lack of proper physical planning and management of land use.The findings finally revealed that land use changes especially decline in sugarcane farming brought economic downfall to society since most farmers earned their living from it. The study recommended that information about land use/cover should be provided consistently to control discipline on human and natural action on land having human dimension as greatest factor of land use/cover change. The technique can aid in proper management of land use as planned.Remotely sense data therefore should find use in all fields of application with agreeable results.
\end{abstract}

Keywords: Land use/cover, GIS and Remote Sensing, Error matrix accuracy assessment, Data integration

\section{Introduction}

In economics, land is one of the three factors of production beside Labour and capital. Land considered as the primary among the natural resources found within a nation [1]. Land the foundation of all forms of human activity, from it we obtain the food we eat, the shelter we need, the space to work and the room to relax.The activities and inputs people undertake in certain land cover type produce change or maintain it.

According to Subramani, changes in land cover occur even in the absence of human activities through natural process [2]. Social-economic and environmental factors are involved for the changes in morphology and land cover and varies considerably from place to place.Agriculture sustains generations through many ways but the most fundamental is direct food or crop products that people need in order to live, if this spatial sector is threatened, then food insecurity rises.

Land use under agriculture therefore keenly need be protected against invasion by other land use and if need be then the invasion should be minimal and controlled. Sugar and sugar products have highly contributed to economic growth at both local and national level. Sugar is immensely used to manufactures various kinds of human consumption staffs, therefore to avoid loss of this crop then proper measures should be put in place to control spatial encroachment based on timely land use/cover information.
Agriculture in Kenya leads in the activities and inputs people undertake on land relies heavily on small scale farmers for cane supply but [3], said failure to pay farmers on time has resulted to accumulated arrears. According to Kweyu this has led to a significant number of farmers abandon cane growing for other crop farming [4]. He also mentioned payment challenges resulted to thousands of farmers opting for other crops where maize and beans were main preferred alternative.

Not only in Kenya elsewhere in Bangalore, Karnataka India sugar farmers shifted to maize and other cash crop in the year 2009.Rajyashree reported that their primary reason for the shift was high cost of cultivation and unattractive prices offered by the Indian Government[5]. The other reason for losing interest in the cane farming was the long growing periods. In Kenya Most of the land under sugarcane is owned at individual level, they are therefore at liberty in deciding on how to use their land. The decisions can be taken based on individual land owners or other entity that controls individual owners. Meaning there is no proper policy and regulation on land use.

Remote sensing data is mainly used to determine what the earth surface is covered of at some point in time. Comparing timely satellite images using change detection methods may result to change or no change. Aspects mainly considered when analysing change detection include detecting the occurred change, identify the specific feaure where change 


\section{International Journal of Science and Research (IJSR) \\ ISSN (Online): 2319-7064 \\ Index Copernicus Value (2013): 6.14 | Impact Factor (2014): 5.611}

have been detected, measure the spatial change and assess the spatial pattern of change. Land use/cover change may result to great damage or benefit to the society in terms of environmental, social and economic impacts. Therefore monitoring land use/cove limit misuse of land and haphazard encroachment to economic usage of space and encourages positive impacts that come along with proper usage of land. GIS and Remote Sensing so far is a technique that has reformed the world through its timely information that greatly support monitoring and management of features on the earth surface.ArcGIS integrates data and supports workflow for collection, production, management and feature exploitation. It also has the capability to display for visualization interpretation and analysis.

Uncontrolled land use has previously been experienced in many parts of the world before this Remote sensing technology come in existence but with the embracement of this technology a lot has changed in management of land cover enabling planning and monitoring of land resource usage in the right way. Controlled land use eliminates challenges that result due to lack of planning and management.A ccording to Weda for a very long time, sugarcane farming was a backbone of Western Kenya economy [6]. In the recent past, the story is slowly changing due to illegal sugar imports among other factors. Sugar factories in western Kenya that have supported sugarcane farmers have collapsed one by one. Opanga continues to argue that MumiasSugar Company (MSC) the jewel in the crown of Kenya's sugar industry announced a loss of 1.6 billion same study area had 25 administrative sub-locations as per census 1999 but increased 33 sub locations as per census 2009. It covers an approximate total area of 59, 000 $\mathrm{km}^{2}$ dominated by Wanga people of the Abaluhya community. Initially for the sake of security and farming, families stayed together and left the bigger part for land for farming. Traditionally women bore many children to help them in farm labour since modern farm technology was not affordable.

Regional economic activities include crop and livestock farming with maize and sugarcane as most significant crops. "Ugali" is the traditional food also known as "Obusuma" in Luwanga made from either maize or cassava or millet flour, a meal is never complete without some "ugali". MSC is the cover.According toOkoth [3], the sugar industry is known to be a major contribution to the agricultural sector, which is one of the mainstays on the kenyan economy and support live hood of at least $25 \%$ of the Kenyan population. If well managed it could play a major role in the country's economic growth. The subsector accounts for about $15 \%$ of the agricultural Gross Domestic Product (GDP), and the dominant employer and source of livelihoods for most households in Western Kenya comprising Nyanza, Rift Valley and Western regions.

Okoth [3] 85\% the total area under sugarcane in Kenya belong out growers who are basically small-scale farmers. The remaining area is largely under sugar companies known as nuclear estates. Factories depend on farmers to supply the sugarcane for processing. In Kenya there are three major sugar belts namely Nyando, the Western Sugar belt and the
South Nyanza that have majored in sugar production in support of the Kenyan economy.

Farmers used their fields entirely on sugarcane farming from which their produce earned them income to sustain their domestic needs.Various factors such as economic, Government and company policy, culture, population, household level decisions, technology and size of land among others are likely to influence greatly land use/cover of a point in time. Some of this factors have contributed to the reputation of this region became a past tense.The miller period, Sugar factories owned by the government announced a combined loss of 6.1 billion[7]. Basing on the loss, farmers are giving up on sugarcane farming which was once a cash crop and opting for other alternative crop. Kennedy found out that maize is the main staple food crop in Western Kenya [8].

It is in line with the background that the study gets to assess the level of land use change in the region using three epochs 1984, 2000 and 2015.According to assessment Bayan et al land use/cover changes can be achieved by using different satellite data such as Advance Space born Thermal Emission and Reflection Radiometer (ASTER), Landsat, Satellite pour l'Observation de la Terre (SPOT), Synthetic aperture radar (SAR) and Aerial photograph[9]. Remote sense data together with GIS technology are widely recognized and are cost effective and accurate in gathering data and analysing its spatial distribution of land use/cover. In this case Landsat data was used to determine the characteristics of land use/cover.

\section{Problem Statement}

Land use/cover changes are pervasive with no clear understanding of their spatial extends, drivers and impacts to societyin Mumias District. Conventional driving forces bring serious losses of agricultural land, vegetation and land water bodies. Mumias District is not an exception; much has changed gradually from typically known sugar zone in terms of land use in the last 34 years. Much of the land under sugarcane in the region is feared to have reduced and instead replaced by other uses such as settlement, expansion of towns and other agricultural crops.The sugar industry in Kenya is witout a dought in chaos. This has resulted in an increase in poverty amongst farmers and inefficient growth of the subsector.Mumias and Busia District are ranked as higher poverty class and higher risk in terms of food availability and mulnutrition [12].This indicators have dangerous future implication and are set to worsen if the situation does not change. Discussion with MSC revealed that they have no timely information on land use/cover neccessary to implement land develpment policies. Therefore is still hope for the indusry and therefore theres need to determine the extent to which the land has converted to other use.

\section{Material and Methods}

\subsection{Study Area}

Mumias District is between $00^{0} 36^{\text {ee }} 00^{\prime \prime} \mathrm{N}$ to $00^{0} 24^{\text {ee }} 00^{\prime \prime} \mathrm{N}$ latitude and $34^{0} 21^{\text {ee }} 00^{\prime \prime} \mathrm{E}$ to $34^{0} 39^{\text {"e }} 00^{\prime \prime} \mathrm{E}$ longitude (Figure 


\section{International Journal of Science and Research (IJSR) \\ ISSN (Online): 2319-7064 \\ Index Copernicus Value (2013): 6.14 | Impact Factor (2014): 5.611}

1) with landscape relatively flat. Rainfall within the region is relatively high and range between $1295 \mathrm{ml}-2281 \mathrm{ml}$ per year. There two main rain seasons, long and short which begins every March and September months of the year and favours the growth of sugarcane, maize, and beans crops. River Nzoia is the only natural resource apart from land.It crosses through the study area and drains to Lake Victoria.

As per 2009census, it had an urban population of 359, 373 persons accumulating to $0.003 \%$ population of Kenya. The oldest and biggest sugar factory in Kenya found within the region.Initially the factory was managed by its founders known as British Booker Teta before handing over to Kenyan Government.The Booker Teta attracted massive growing of sugarcane, which was a primary source of income.

The choice of the study area based on the personal experience on the region and the fact that most of the sugar consumed in the country is from the same region. The study area is the largest sugar zone in the country where sugarcane was prevalent, and produced approximately 60 to $65 \%$ of the total sugar countrywide [10].

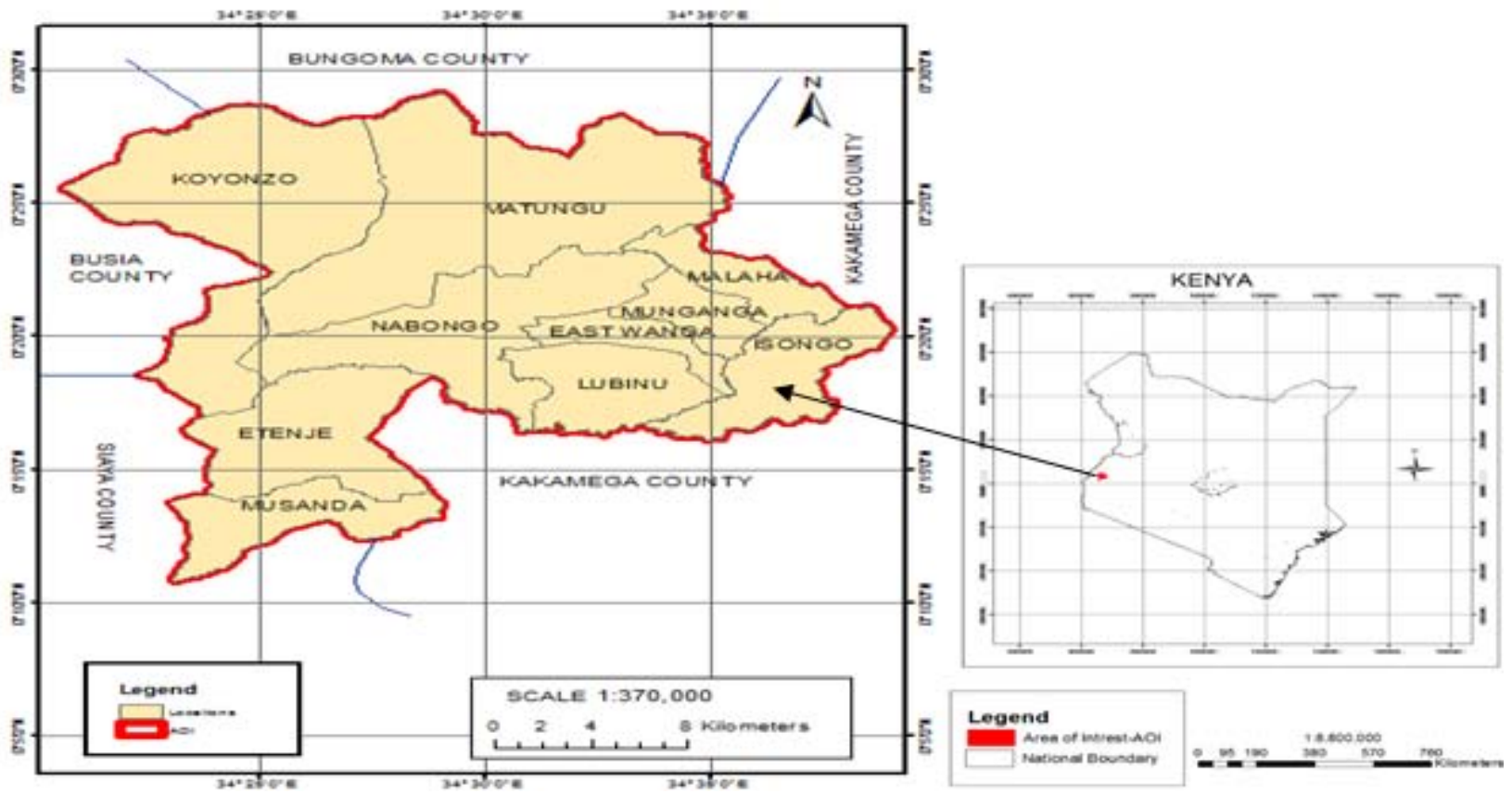

Figure 1: StudyArea and Location map of Mumias District

Table 1: Data Source

\begin{tabular}{|c|c|c|c|c|c|}
\hline \multirow{2}{*}{ Item } & Date of production & $\begin{array}{c}\text { Spatial } \\
\text { Resolution }\end{array}$ & $\begin{array}{c}\text { Total } \\
\text { Number }\end{array}$ & Source of Data & Processing from source \\
\hline Landsat5 & $15 / 8 / 1984$ & $30 \mathrm{~m}$ & & USGS & UTM, WGS84 Ellipsoid, Zone 36 \\
\hline Landsat7 & $2 / 8 / 2000$ & $30 \mathrm{~m}$ & & USGS & UTM, WGS84 Ellipsoid, Zone 36 \\
\hline Landsat8 & $27 / 7 / 2015$ & $30 \mathrm{~m}$ & & USGS & UTM, WGS84 Ellipsoid, Zone 36 \\
\hline Google Earth SPOT & $31 / 7 / 2015$ & $0.8 \mathrm{~m}$ & & Google & UTM, WGS84 Ellipsoid, Zone 36 \\
\hline Top sheets 01/2\&4, 102 & 1970 & $1 / 50,000$ & & SOK & Scanned copy \\
\hline Road network & & & & KNBS & Shapefile \\
\hline \multirow{2}{*}{ Population } & & & & KNBS & Excel \\
\hline \multirow{2}{*}{ Household } & 1999 & & 276,932 & KNBS & Excel \\
\cline { 2 - 5 } & 2009 & & 63,062 & KNBS & Excel \\
\hline \multirow{2}{*}{ Rainfall } & 1999 & & 78103 & KNBS & Excel \\
\hline
\end{tabular}




\subsection{Flow Diagram}

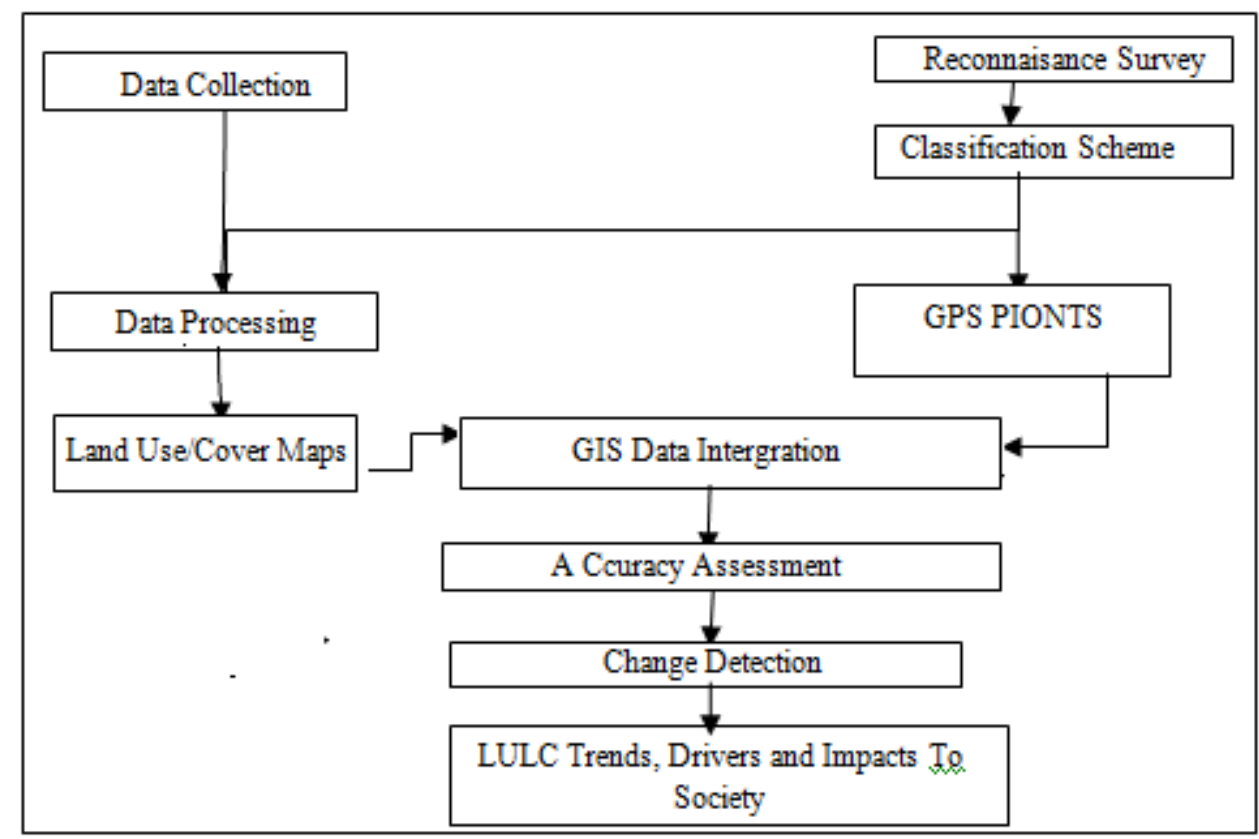

\subsection{Data Acquisition and Preparation}

Type of data involved were primary and secondary data of which Primary data collection involved actual field visit to capture GPS feature points and also familiarize with the local area. Secondary data collected from different sources composed of different kinds such as Landsat images, population data, Top sheets, Google earth, road and Rainfall data among others (Table1). Before use, the validity of data was necessary for instance, publication date, accuracy, reliable sources and geographical locations. Landsat5 TM, Landsat7 ETM+, and Landsat8 (Figure 3) acquired from United States geological surveys website (glovis.usgs.gov). Landsat and Google Earth image overlaid each other automatically since they were in the same coordinate system.

To avoid spectral difference all image were restricted to same period and of cloud cover, less than $10 \%$.The study area was extracted from Kenya administrative boundaries map. Three topographical sheets 101/2, 101/4 and 102/1 were mosaicked to extract the study area.Landsat images and Google Earth (SPOT) were already geometrically corrected at source with coordinate system UTM WGS84. Despite most of the required data being geospatial, topographical sheets were not in same coordinate system and therefore projection and transformation to UTM WGS84 was necessary to enable integration of data during analysis.

Accurate analysis requires image preparation to clean the image out of unnecessary errors [11]. The process under taken for image pre-processing included spatial Subset Calibration, Pan sharpening and Enhancement to facilitate extraction of accurate information. ENVI 5.1 Software was used to perform all image pre-processing and image processing operations. The ENVI service have added support sensor that includes file open using the metadata and can display multiple views at the same timework with multiple layers of data in one window and allow manipulation of remote sensed images, in terms of vectors and annotation. For data integration, ENVI provides access to Arc-Map tools as it works well with layers.

\subsection{Data Processing}

Two important issues at this stage were choice of classes for image classification and choice of band combination. The classification subjectively meant to suit the needs of user who for this case are MSC, Kenya Sugar Board, local Agricultural officer and farmers to assist them in

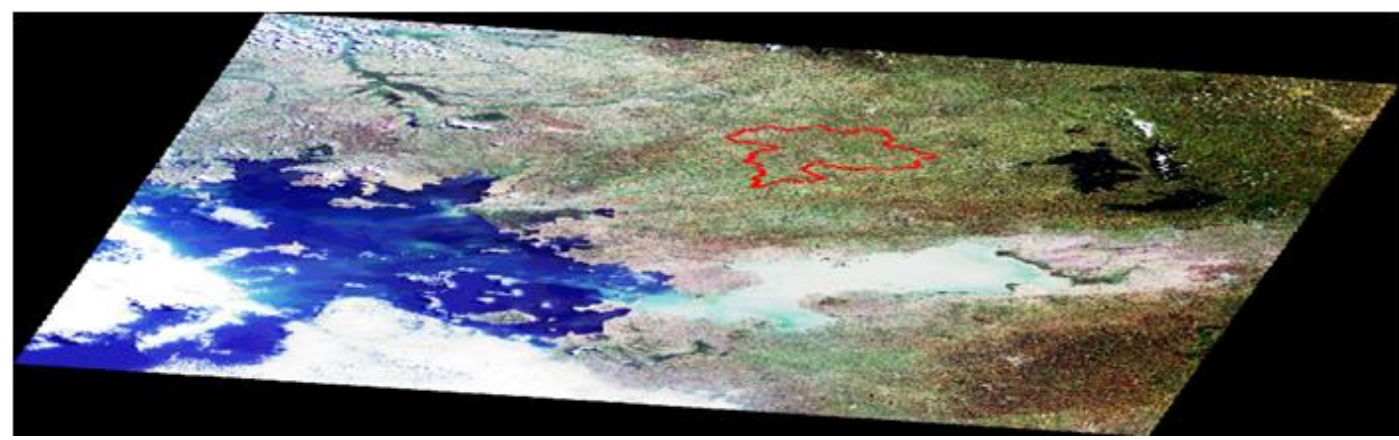

Figure 3: Landsat8 image scene of 2015 showing AOI

Volume 5 Issue 2, February 2016 


\section{International Journal of Science and Research (IJSR) \\ ISSN (Online): 2319-7064 \\ Index Copernicus Value (2013): 6.14 | Impact Factor (2014): 5.611}

Planning, management and usage of land in this zones. The study used Supervised classification method with Maximum algorithm.This method uses sample pixels located on the image based on prior knowledge of the person processing.The prior knowledge can be field data, aerial photograph and local knowledge about the study area. Despite the prior knowledge this could not work without support of high resolution image SPOT.The high resolution image assisted in interpretation and location of features on Landsat images through matrix overlay operation (Figure 4) using ENVI 5.1 software.Colour Infra-red (CIR)was used to delineate the image classes.

\subsection{Data Integration}

Combination of different data from different source assists in interpretation and analysis. Data sets included multitemporal, multi-resolution, multisensory and multi data type.The purposeof data integration is to extract better and/or more information. Road data overlay on the classified image and overlay of multi-temporal vector layers generated new perspectives on the model themselves.ArcGIS an ideal tool was used to combine different data in a unified geography view.

\section{Result, Conclusions and Recommendations}

\subsection{Result}

Vegetation in CIR really pops out red with healthier vegetation being more vibrant. In this case sugarcane appeared in shades of red due to varying growth stages while other Vegetation especially trees appeared dark red. Non vegetated areas such as Built up appeared in blue and grey while dry maize in purple and finally water bodies in cyan (Figure 5).

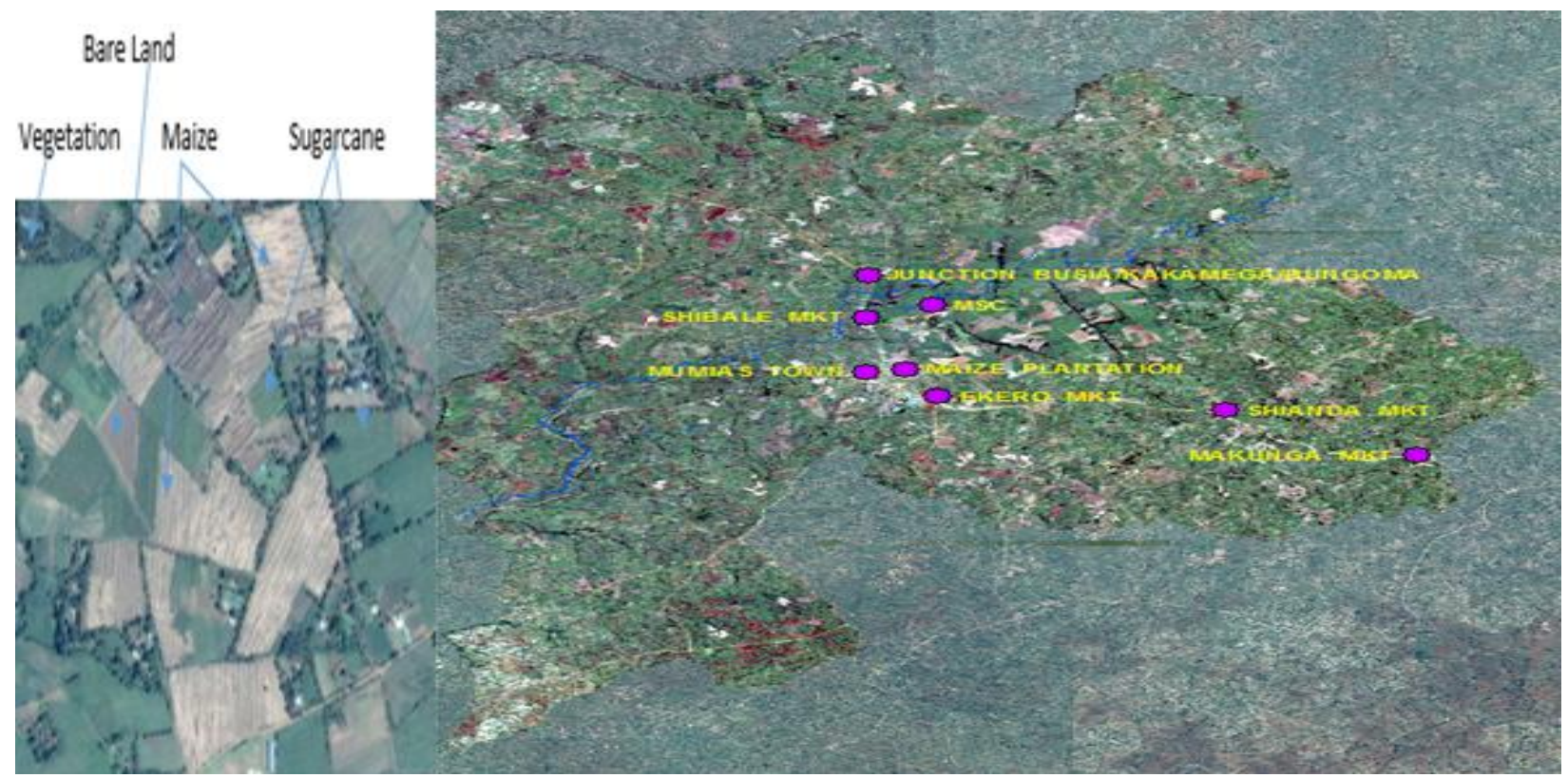

Figure 4: Google Earth and satellite image overlay

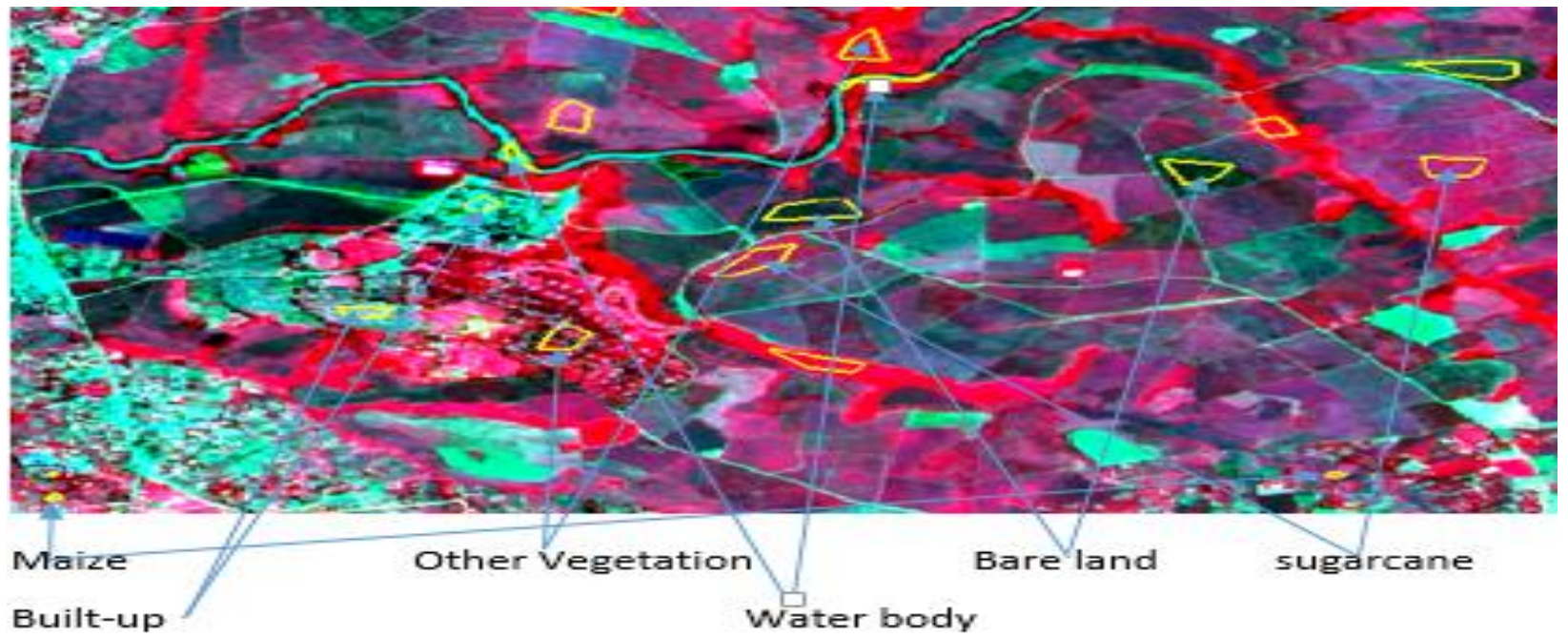

Figure 5: Signature annotation on a Satellite image loaded in Colour infrared (CIR).

A land use/cover image map resulted from processed data showing the six information classes as sugarcane, maize, other vegetation, built-up, water body and barren land.1984 epoch (Figure6) more Sugarcane was farmed and especially 


\section{International Journal of Science and Research (IJSR) \\ ISSN (Online): 2319-7064 \\ Index Copernicus Value (2013): 6.14 | Impact Factor (2014): 5.611}

in eastern side where MSC is established while Other vegetation class much of it was in the western side. Maize like other vegetation much of it was in the western side but scarcely farmed on the eastern side. Nuclear type of settlement was seen in the entire image some how evenly spread. Along the road stretching from southeast to northwest linear settlement was noted. Water body especially river Nzoia running from northeast to southwest and cuts across the study as the main water body. Likewise, one main tarmac road cut across the area from northwest to southwest with a diversion towards northeast from near the center. All the six classes were present and clear unlike 2000 and 2015 classifie images ( Figure 7 and 8)

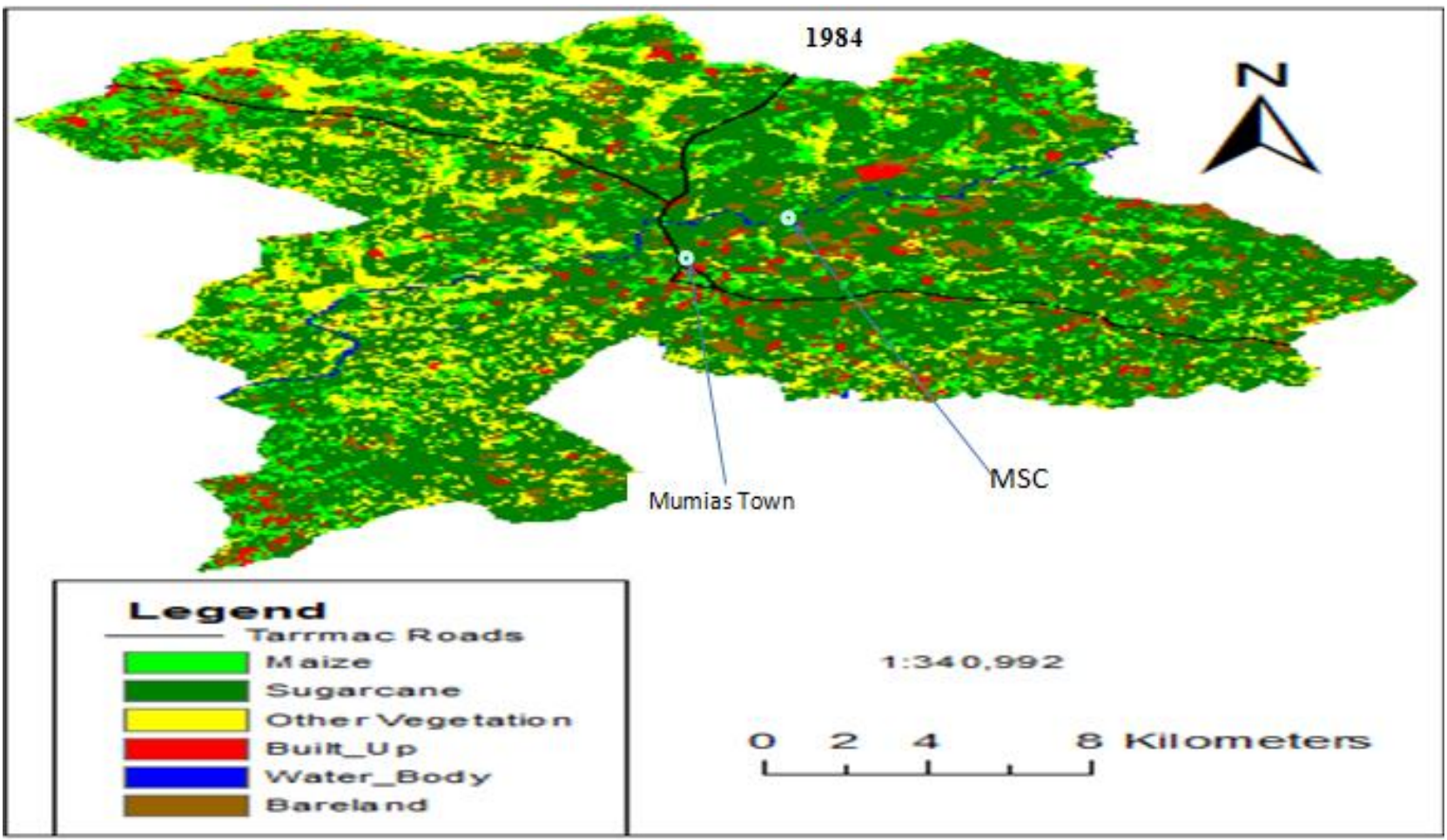

Figure 6: Land use/cover classification of Mumias District based on Landsat TM

In figure 7 below sugarcane, maize, other vegetation and bare land, was seen in all direction except the nuclear field around MSC that allows only sugarcane crop. Built up class showed nuclear type of settlment and just alittle of linear along the road.

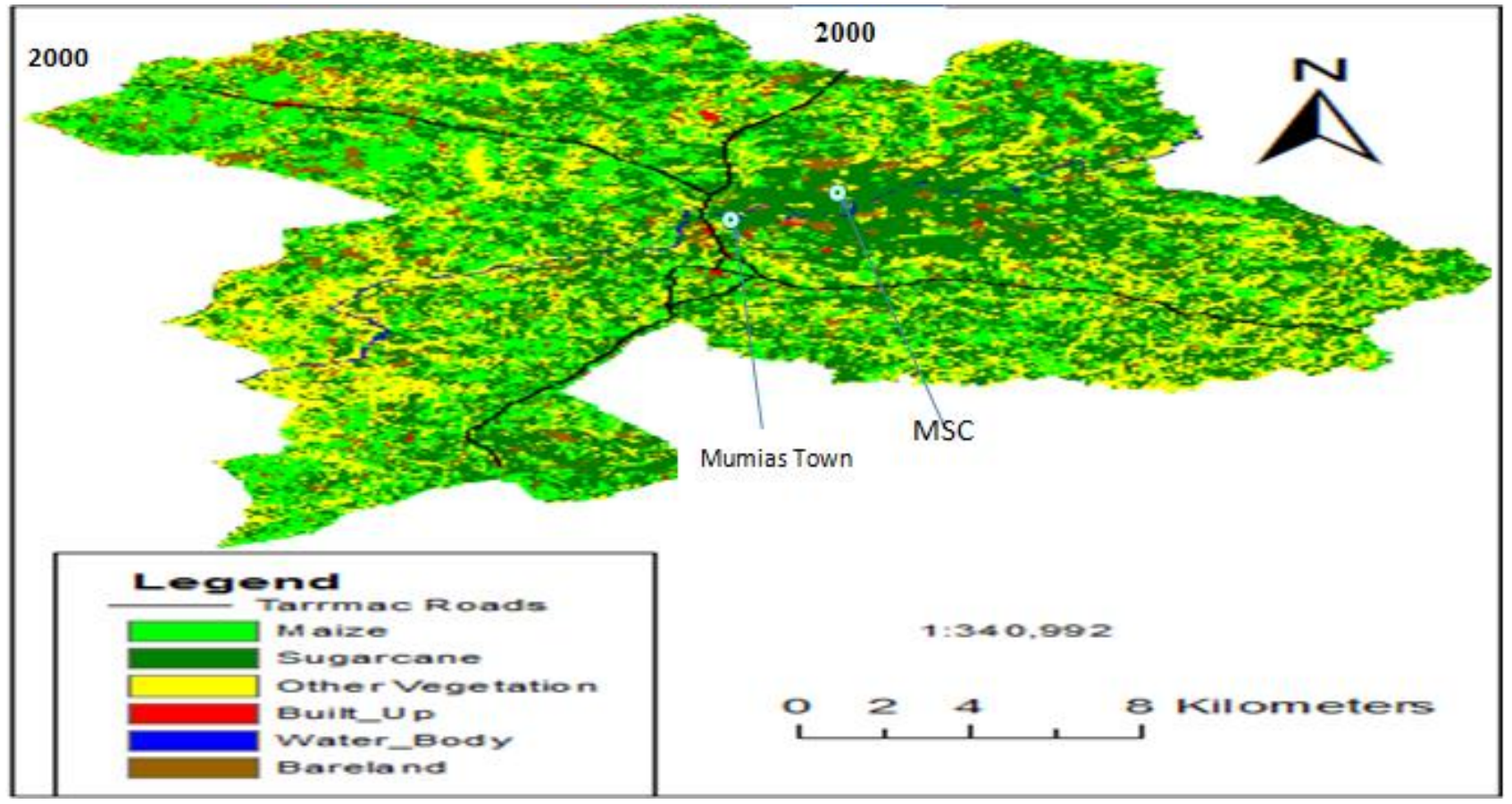

Figure 7: Land use/cover classification map of Mumias District based on Landsat ETM+ 


\section{International Journal of Science and Research (IJSR) \\ ISSN (Online): 2319-7064 \\ Index Copernicus Value (2013): 6.14 | Impact Factor (2014): 5.611}

In figure 8 below maize was spread in all direction and likewise to build up, in both some areas were more dense than others while sugarcane appeared in small parches in all direction.Other vegetation seemed to be almost absent except around the MSCand bare land like sugarcane appeared in parches.

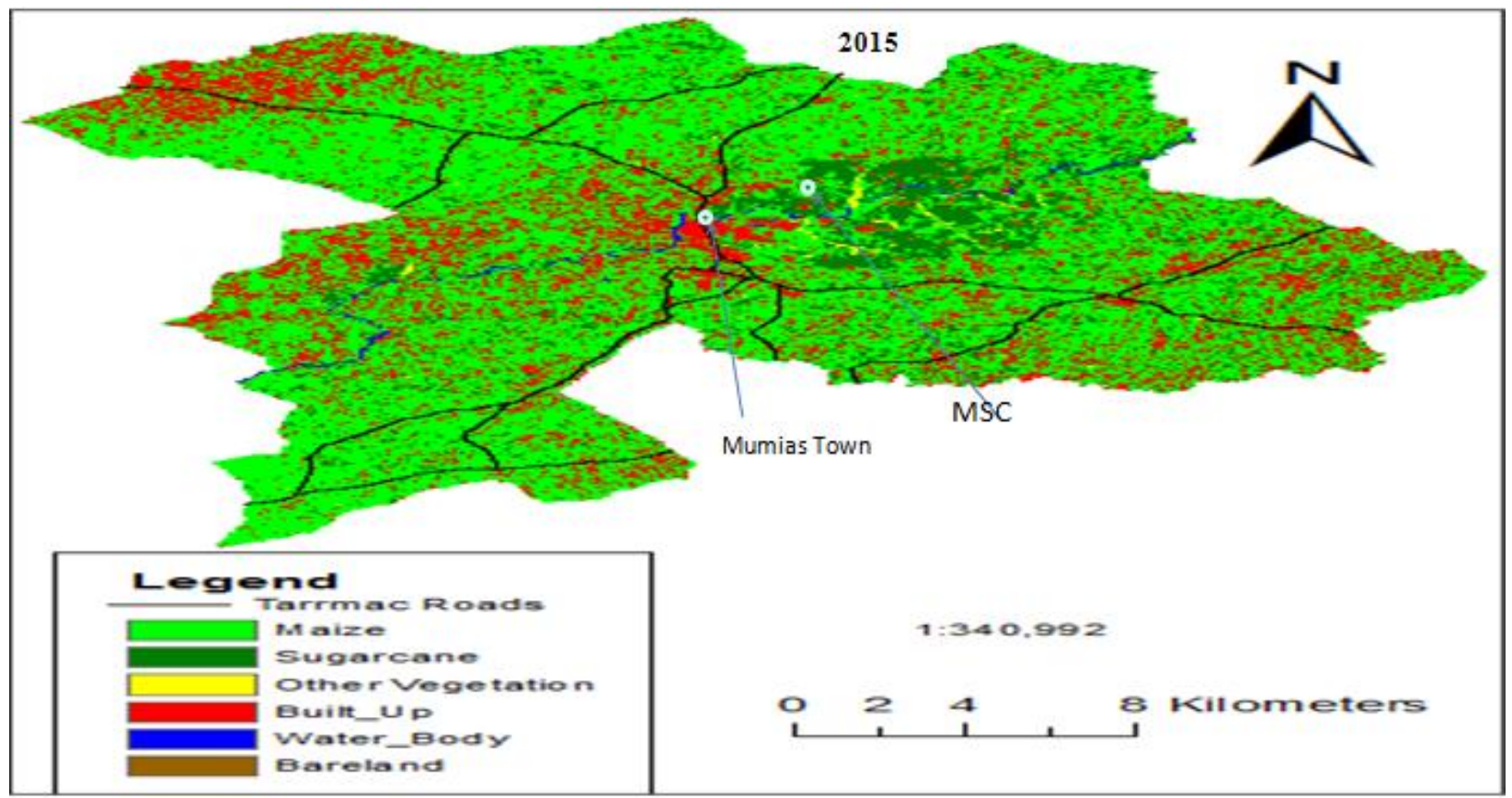

Figure 8: Land use/cover classification map of Mumias District based on Landsat

Data integration enabled overlay of road data, accuracy assessment and data analysis for each classified image. Error matrix method is the most recommended in accuracy assessment and is used to assess the accuracy of image classification. This type of accuracy assessment is composed of statistical data (Table 2) namely Kappa coefficient, overall accuracy, User accuracy and producer accuracy. Kappa coefficient lies on a scale between 0 and 1 . The coefficient is categorised into levels, which enable compare model prediction and reality. Kappa coefficient above 0.8 represents strong agreement (complete reduction of error), 0.4 to 0.8 represents moderate agreement and below 0.4 indicates poor agreement. The study yielded a strong agreement having an overall accuracy of $96 \%, 97 \%$ and $99 \%$ with 0.87, 0.89 and 0.99-kappa coefficient for epoch 1984, 2000 and 2015 respectively. Use of a single data set method of accuracy assessment is less recommended but it was tried in this research to see the river Geographical outcome. In this case the topographical sheets and classified image were overlaid and River Nzoia on both classified image and topographical sheet is a clear evident of a strong agreement in the absence of error matrix method since they overlaid each other perfectly (Figure 9). Single data accuracy assessment is rarely used after realization of Error matrix accuracy assessment since Error matrix assessment is of higher accuracy and the most preferably used.From the results, all the classified images were of strong agreement indicating high accuracy. Landsat8 yielded the best accuracy 0.99 (Table 2) and this was because it has 12 bits of the operational land imager (OLI) and Thermal Infrared Sensor (TIR) higher than previous Landsat in this case as TM and ETM+ which have 8 bits. The higher the number of bits, the higher the ability to detect changes on the surface of the earth.
Table 2:Error matrix of land use/cover maps of Landsat

\begin{tabular}{|c|c|c|c|c|c|c|c|c|}
\hline \multicolumn{9}{|c|}{ Landsat5 TM (1984) } \\
\hline Data & 1 & 2 & 3 & 4 & 5 & 6 & Total & $\begin{array}{l}\text { User(s) } \\
\text { accuracy }\end{array}$ \\
\hline 1 & 12 & 25 & 0 & 0 & 0 & 0 & 37 & 32 \\
\hline 2 & 9 & 1109 & 0 & 0 & 1 & 0 & 1119 & 99 \\
\hline 3 & 0 & 19 & 63 & 0 & 0 & 0 & 82 & 76 \\
\hline 4 & 0 & 0 & 0 & 39 & 0 & 0 & 39 & 100 \\
\hline 5 & 0 & 0 & 0 & 0 & 32 & 0 & 32 & 100 \\
\hline 6 & 0 & 0 & 0 & 0 & 0 & 73 & 73 & 100 \\
\hline Total & 21 & 1153 & 63 & 39 & 32 & 73 & & 382 \\
\hline Producer accuracy\% & 57 & 96 & 100 & 100 & \begin{tabular}{|l|l|}
96 \\
\end{tabular} & \begin{tabular}{|l|l|}
100 & \\
\end{tabular} & & \\
\hline \multicolumn{9}{|c|}{ Overall accuracy 96\%, kappa statistic 0.87} \\
\hline \multicolumn{9}{|c|}{ Landsat7 ETM+ (2000) } \\
\hline 1 & 187 & 7 & 3 & 0 & 0 & 0 & 197 & 94 \\
\hline 2 & 0 & 569109 & 1 & 1 & 0 & 0 & 5694 & 99 \\
\hline 3 & 3 & 119 & 14 & 2 & 0 & 0 & 137 & 10 \\
\hline 4 & 0 & 0 & 0 & 133 & 0 & 0 & 133 & 100 \\
\hline 5 & 0 & 0 & 0 & 0 & 77 & 0 & 77 & 100 \\
\hline 6 & 0 & 0 & 0 & 10 & 0 & \begin{tabular}{|l|l|}
242 \\
\end{tabular} & 252 & 100 \\
\hline Total & 190 & 5817 & 18 & 146 & 77 & 242 & \multicolumn{2}{|c|}{6490} \\
\hline Producer accuracy\% & 98 & 96 & 78 & 91 & 100 & 100 & & \\
\hline \multicolumn{9}{|c|}{ Overall accuracy 98\%, kappa statistic 0.89} \\
\hline \multicolumn{9}{|c|}{ Landsat8 (2015) } \\
\hline 1 & 37 & 0 & 6 & 0 & 0 & 0 & 43 & 86 \\
\hline 2 & 0 & 152009 & 0 & 0 & 0 & 0 & 1520 & 100 \\
\hline 3 & 0 & 0 & 587 & 0 & 0 & 0 & 587 & 100 \\
\hline 4 & 3 & 0 & 0 & 145 & 2 & 6 & 156 & 92 \\
\hline 5 & 0 & 0 & 0 & 0 & 111 & 0 & 111 & 100 \\
\hline 6 & 0 & 0 & 0 & 0 & 0 & 438 & 438 & 100 \\
\hline Total & 400 & 1520 & 593 & 145 & 113 & 444 & \multicolumn{2}{|c|}{2855} \\
\hline Producer accuracy\% & 98 & 96 & 100 & 100 & \begin{tabular}{|l|}
96 \\
\end{tabular} & 100 & & \\
\hline
\end{tabular}

1 Maize: 2 Sugarcane : 3 Other Vegetation : 4 Built Up : 5

Water Bodies ; 6 Barren Land 


\section{International Journal of Science and Research (IJSR) \\ ISSN (Online): 2319-7064}

Index Copernicus Value (2013): 6.14 | Impact Factor (2014): 5.611

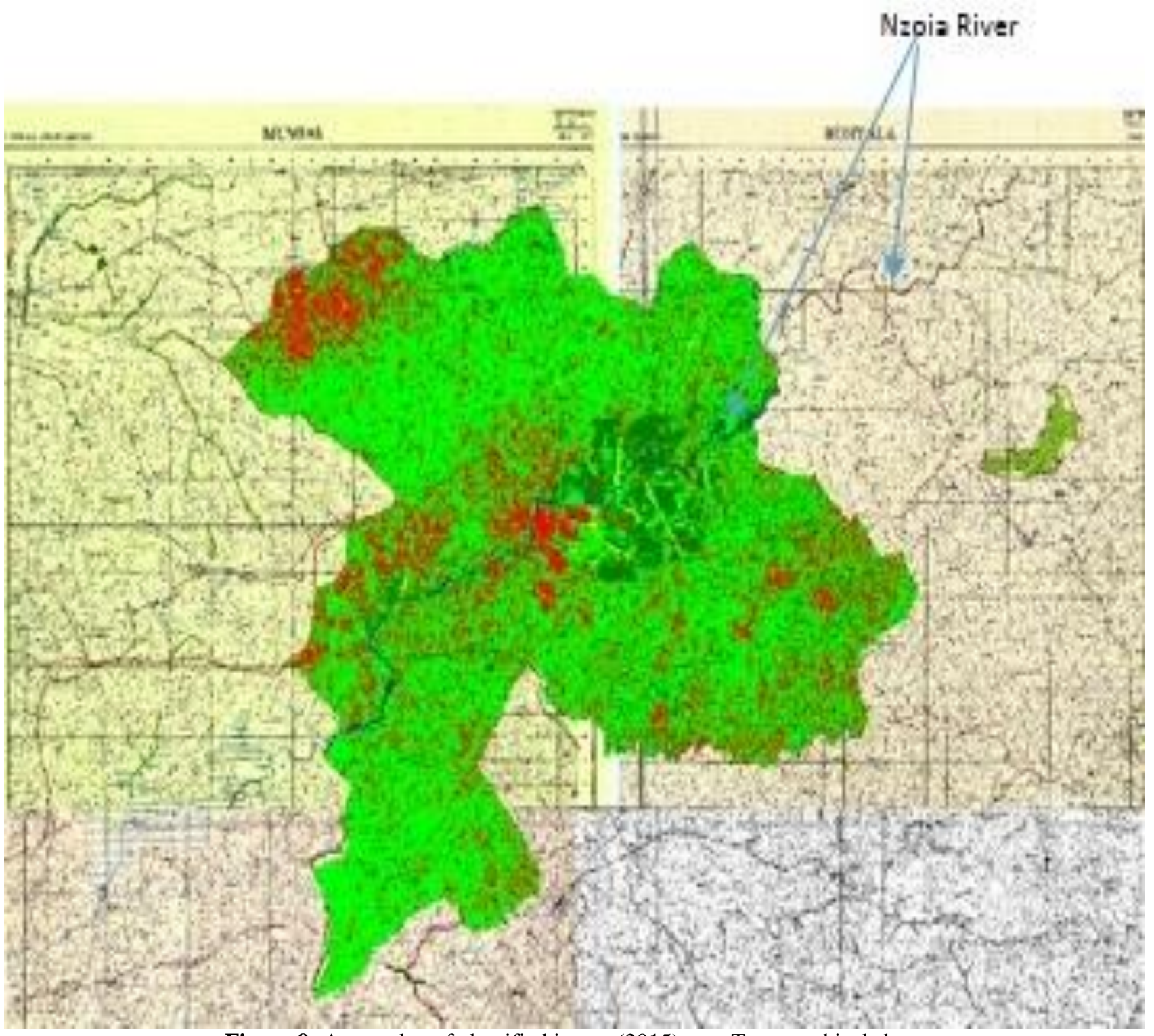

Figure 9: An overlay of classified image (2015) on a Topographical sheet

Table 3: Land use/cover spatial extent (1984, 2000 and

2015)

\begin{tabular}{|c|c|c|c|c|c|c|}
\hline \multirow{2}{*}{ Classes } & \multicolumn{2}{|c|}{1984} & \multicolumn{2}{c|}{2000} & \multicolumn{2}{c|}{2015} \\
\cline { 2 - 8 } & $\begin{array}{c}\text { Area } \\
\left(\mathrm{km}^{2}\right)\end{array}$ & $\%$ & $\begin{array}{c}\text { Area } \\
\left(\mathrm{km}^{2}\right)\end{array}$ & $\begin{array}{c}\text { Area } \\
\left(\mathrm{km}^{2}\right)\end{array}$ & $\%$ \\
\hline Maize Plantation & 7820.5 & 13 & 15641.1 & 27 & 39380.2 & 67 \\
\hline sugarcane Plantation & 34971.1 & 60 & 23660.9 & 40 & 11459.4 & 21 \\
\hline Other Vegetation & 9519.4 & 16 & 15729.9 & 27 & 198.7 & 0 \\
\hline Built Up/Roads & 2086.4 & 4 & 386.6 & 1 & 6790.3 & 10 \\
\hline Water & 306.9 & 0 & 213.3 & 0 & 239.9 & 1 \\
\hline Barren land & 3961.6 & 7 & 3033.3 & 5 & 597.8 & 1 \\
\hline Total & 58666.9 & 100 & 58666.4 & 100 & 58666.3 & 100 \\
\hline
\end{tabular}

In figure 3 above clearly shows the statistical kilometer squared $\left(\mathrm{km}^{2}\right)$ and percentage (\%) of each class in reference to total area. Each class Spatial extent never remained constant from 1984-2015, instead it varied with time. The class that had the highest spatial extent in respect to total area in 1984 was sugarcane with $60 \%$ and same in 2000 with $40 \%$ while in 2015 was maize with $67 \%$.The least spatial extent was water body in both 1984 and 2000 with $306.9 \mathrm{~km}^{2}$ and $213.3 \mathrm{~km}^{2}$ respectively while in 2015 was other vegetation with $198.7 \mathrm{~km}^{2}$ spatial extent.

Volume 5 Issue 2, February 2016 www.ijsr.net 


\section{International Journal of Science and Research (IJSR) \\ ISSN (Online): 2319-7064}

Index Copernicus Value (2013): 6.14 | Impact Factor (2014): 5.611

\subsubsection{Driver of Land Uses/cover}

(a) Size of Land

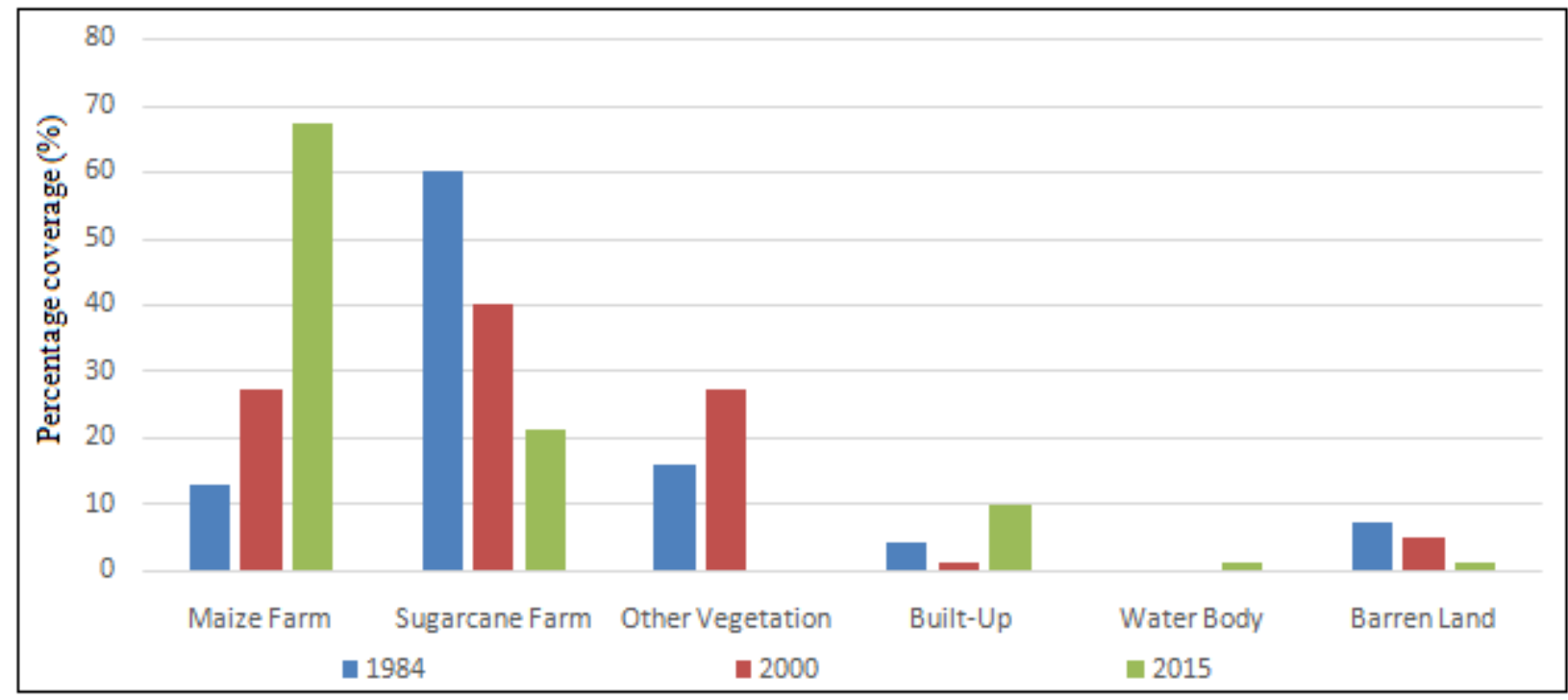

Figure 10: land use/cover type

In figure 10 above the size of land for maize kept increasing with time whereas sugarcane decreased. Other Vegetation class showed decrease in 2015 while built up and water body (b) Population increased the same year. Bare land like sugarcane continuously reduced thought the period.

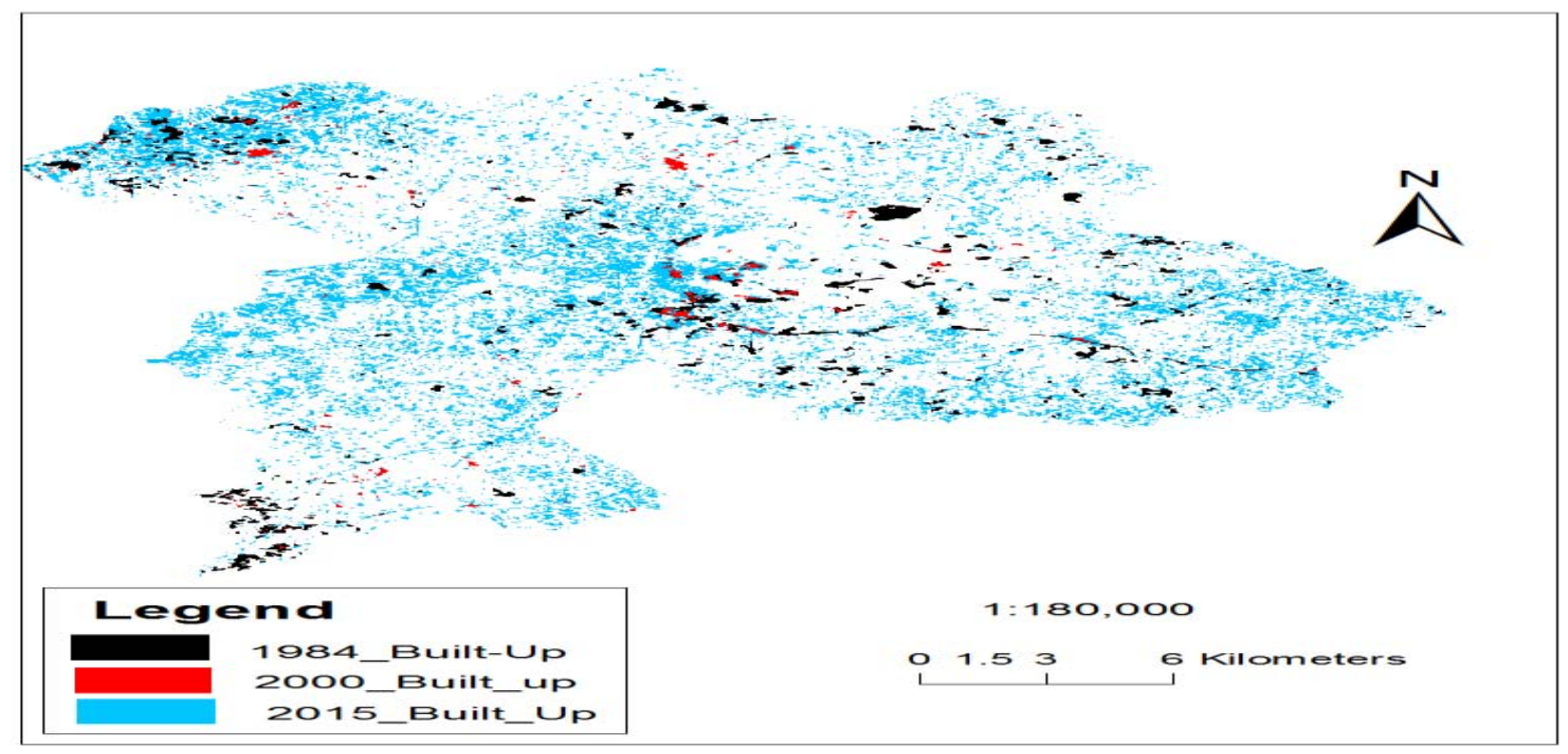

Figure 11: Population Spatial Change

In figure11 above shows population, distribution of the study area of the three epochs realized through the built up class. It is clear that population existed in almost all direction in each epoch with varying densities. 2015 had the highest population while 2000 had the least as evidenced by the distribution. 


\section{(c)Transport}

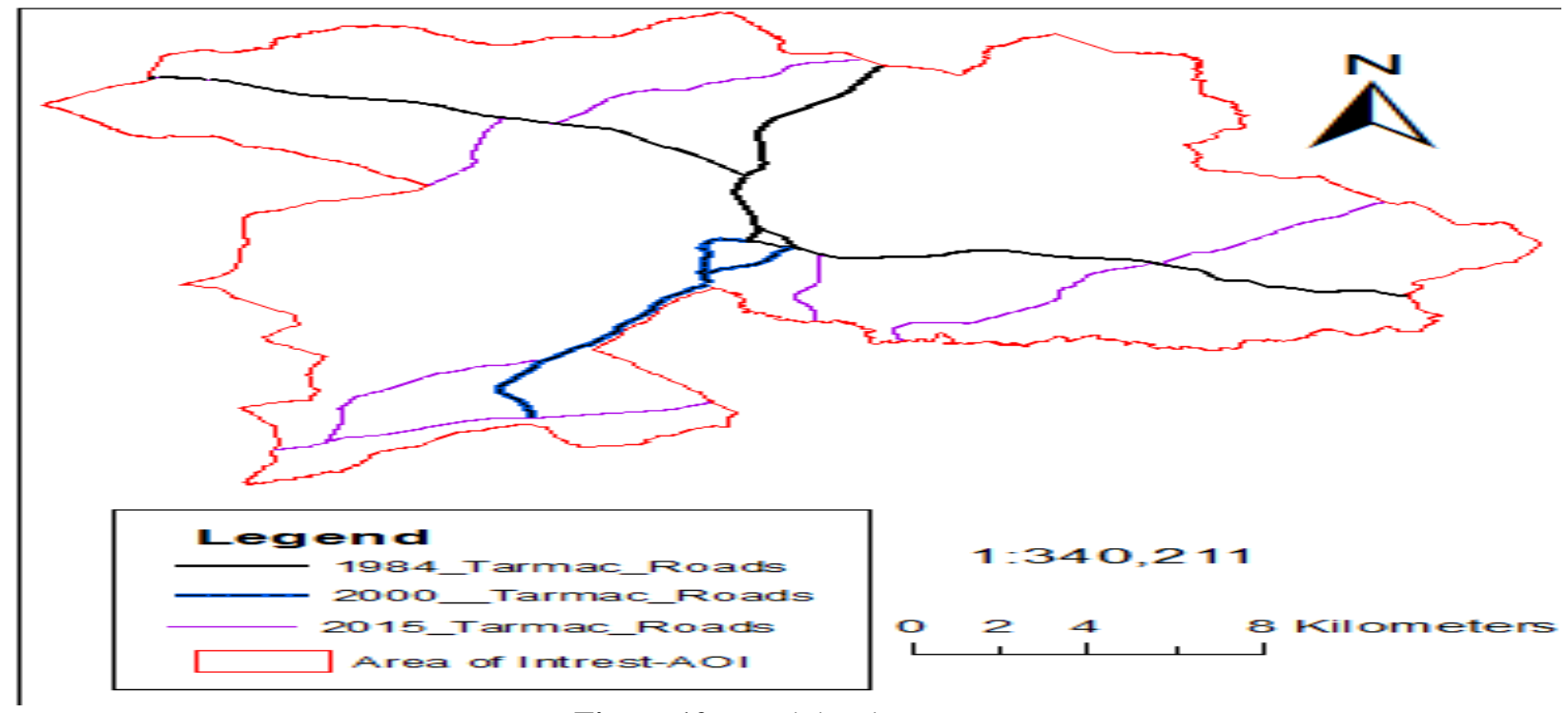

Figure 12: Road developments

Road developments picked up from the existing road of 1984 branching to other parts of the study area. 2015 had the most roads developed (Figure12).
4.2 Impacts of Land use/cover change to society

(a) Economic Impact

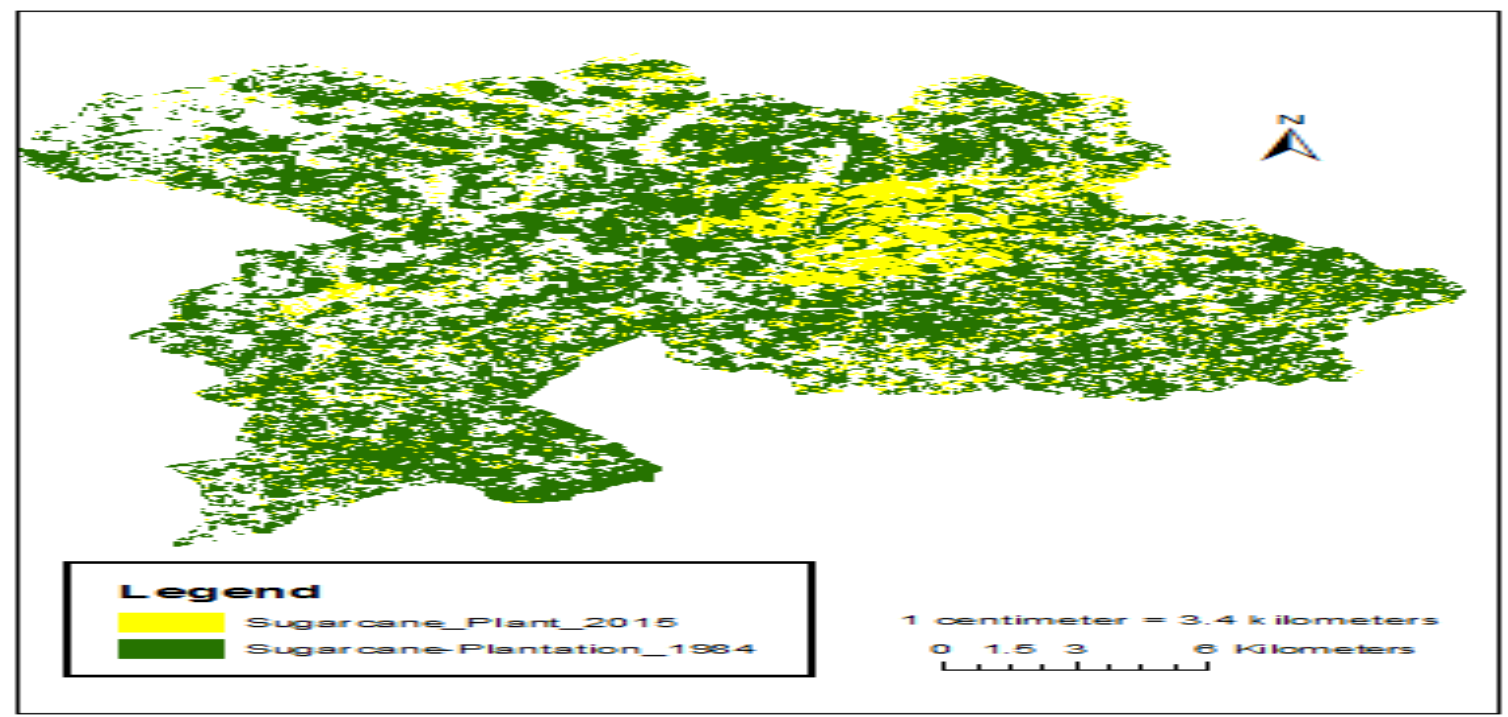

Figure 13: Sugarcane fields spatial changes

(b) Population Densification per $\mathbf{k m}^{2}$

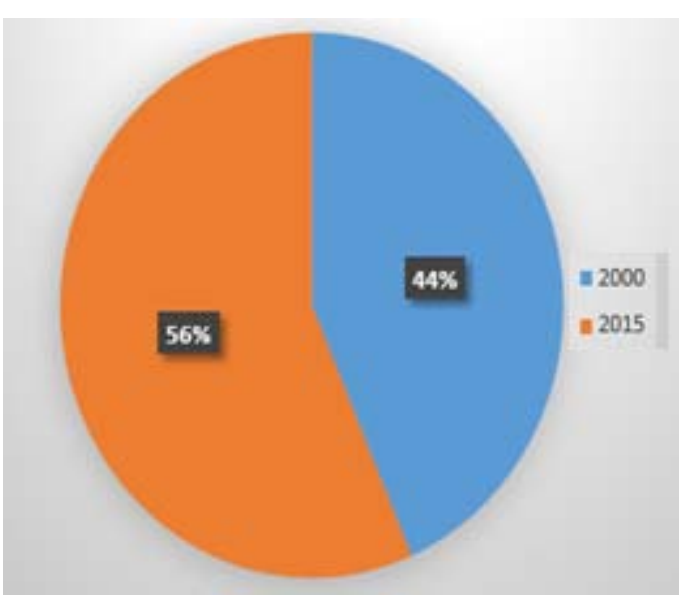

Figure 14: space densification changes

Volume 5 Issue 2, February 2016

www.ijsr.net 


\section{International Journal of Science and Research (IJSR) \\ ISSN (Online): 2319-7064 \\ Index Copernicus Value (2013): 6.14 | Impact Factor (2014): 5.611}

The two epochs 1984 and 2015 (Figure 13) have even distribution of sugarcane in all direction except with varying densities, but 2015 epoch have the least sugarcane distribution. Space densification increased from 44\% to54\% (Figure 14) evidenced also in Built up classes where this class increased tremendously ( Figure 11 and Table 2)

\subsection{Land Use/Cover Analysis}

The findings on land use/cover image map from processed data showed six information classes as sugarcane, maize, other vegetation, built-up, water body and bare land except road network.Most classes experienced change in almost all directions except the water body class. Statistically the decline of sugarcane was $60 \%$ to $21 \%$ (Table3) in the period of study. Maize and Sugarcane showed the most significant changes among the classes with 54\% increase and 39\% decrease respectively between the 1984 and 2015 epochs.Built up class had overall 6\% change. From statistics (Table 3) percentage changes in sugarcane farms decreased from $60 \%$ in 1984 to $40 \%$ in 2000 and finally $21 \%$ in 2015. Maize however, increased from $13 \%$ in 1984 to $27 \%$ in 2000 and finally $67 \%$ in 2015.Built-Up class decreased from $4 \%$ in 1984 to $1 \%$ in 2000 and increased to $10 \%$ in 2015. Other Vegetation increased from 16\% in 1984 to $27 \%$ in 2000 and decreased tremendously to $0 \%$ in 2015 . Water body remained with minor changes of which 1984 to 2000 had no change except 2015 of 1\% increase. Bare land experienced an increase from 7\% in 1984 to 5\% in 2000 and later decreased to 1\% in 2015.

Spatial extent in $\mathrm{km}^{2}$ indicate that the sugarcane fields decreased by $23511.7 \mathrm{~km}^{2}$ between 1984 and 2015. This also is evidenced by a matrix overlay of sugarcane vector layer of 1984 and 2015 (Figure 13) which clearly showed a significant change that occurred in a span of 31 years Of study for sugarcane fields alone. In contrary maize fields increased significantly by $31559.1 \mathrm{~km}^{2}$ in the study period. Bare land decreased by $3363.8 \mathrm{~km}^{2}$ while Other Vegetation increased by $6210.5 \mathrm{~km}^{2}$ from 1984 to2000 and later decreased by $15531.2 \mathrm{~km}^{2}$ from 2000-2015.Built Up decreased by $1699.8 \mathrm{~km}^{2}$ from 1984 to 2000 and later increased by $6,403.7 \mathrm{~km}^{2}$.Water Body decreased by 93.3 $\mathrm{km} 2$ from 1984 to 2000 and later increases by 26.6km2 in 2000 to 2015 indicating least change experienced among the classes.

The driving forces included population, size of land and road developments while economic and space densification were the impacts felt. Lack of proper management resulted to population encroachment into other land use fields haphazardly in search of space to live and work. Lack of stability in size of land per class over period of study indicated lack of defined land use boundaries in place. Decrease in land size under sugarcane paved way to increase in maize as the major alternative. Road development changed settlement pattern as clearly seen in the last epoch of study where linear settlement was more along major roads compared to other epochs (Figure.6-8) Other drivers not possible to present graphically yet affects the study land use/cover included Government policy, company policy, household level decisions and cultural factors.
The study evaluated the impacts on economic drop and rise in space densification which were graphically reperesented. Decline in sugarcane farming brought economic downfall since most locals including farmers earned from it. Sugarcane distribution in the region clearly determines the economic factor of this region (Figure 13).Farmers have almost $85 \%$ of the total area under sugarcane [3]. Sugarcane tremendously declined throughout the period of study as evidenced in land use/cover type (Figure 10 and table 3) in an alarming way with no action on remedy taken.

Space densification increased because of increase in population and development of road which eased accessibility of farm goods. Reduction in Bare land in the last epoch is an indication of most land under use. Population had increased with time as from census 19992009 statics rising from 276932 to 359373 persons recording $30 \%$ rise (Table 1 ). Therefore reflecting the same information on 2000 and 2015 (Figure 14) implies the spatial densification has gone up by $9 \%$ from 2000 .

\subsection{Conclusions}

The study concludes land use/cover changes were realized more in maize and sugarcane. This was evidenced by a tremendous increase in maize farming and reduction in sugarcane farming among other classes. The study also concludes that the major driving forces for land use changes include: size of land, population and road developments. The mix of driving forces varies in time and space in that land that was initially used for sugarcane farming turned out into other agricultural uses. Land use/cover taking another trend by farmers shifting to other crops since sugarcane farming no longer sustained them.Sugarcane is a commercial crop and any further divisions of land into small fragments affect amount of produce and income. The more people in a place continue to move out, in, and within or die the more the land changes through subdivision, sale or purchase. The size of land can change by either gaining or losing. Much of the land is managed by individuals and therefore they are free to make decisions on how to use their land as a property. Both increase and decrease in population also has a large impact on land use since they change density of settlements. Good roads on land use/cover have influenced type of settlement through growth of markets and town's centers and type of farming.

The study finally concludes that decline in sugarcane farming brought economic downfall resultig into: poverty, low education, and increase in price of sugar, death and insecurity.Poverty and death can be explained by the fact that when the economy is down, then there is no money in circulation and this leads to growth in poverty index day by day and decline in the standards of living which further results into loss of hope in life and early death due to psychological problems. Low education in the sense that lack of income can cause so many youth and young children drop out of school because most guardians depended on money from sugarcane produce. Low cane supply to the factory means low sugar production to an extent of Kenya Government importing sugar to meet the high deficit and making sugar prices go up. Increase in insecurity amongst 


\section{International Journal of Science and Research (IJSR) \\ ISSN (Online): 2319-7064 \\ Index Copernicus Value (2013): 6.14 | Impact Factor (2014): 5.611}

young men who worked in both sugarcane fields and factory resot to anti-social behavior such as thuggery

\subsection{Recommendations}

The study recommends that information on land use/cover should be provided consistently to control discipline on human and natural action on land having human dimension as greatest factor of land use/cover change. The richness of the archive allows users to exploit time series data to establish long term trends and monitor the rate and charectersistics of land surface change.The technique can reformed way of management of earth surface features. Mangement and control avoid the consequences that come as a result of lack of proper management such as economic downfall in this case lack of space for economic activity due to uncontrolled encrouchment of agricultural land and, uphapharzard construction by human populaion. Remotely sense data and GIS is a powerful tool to derive accurate and timely information on land use/cover spatial distribution therefore should find use in all fields of application with agreeable results.

The study further recommends that the driving forces such as population, transport infrastructure and land size should be controlled. This can be done through controlled settlement and cosolidation of Agricultural land. The fact that sugarcane is a commercial crop that requires large-scale farming, agricultural sector under sugar board of Kenya should use this technique and information to come up with policies concerning management and monitoring of sugarcane spatial fields. Sugarcane cover is under risk invasion in this zone and needs quick intervention to prevent its decline.Farmers have future hope of going back to sugarcane farming, which they love most. However, it is until you know where you physically stand in order to plan, manage and control land use/cover to achieve vision 2030 of sustainable production in the sector.

The study finally recommends that farmers should diversify on other comercial activities which can as well act as source of income. This will help in reducing the negative impacts of land use changes as exploring other commercial activities can act as a source of alterative income.

\section{References}

[1] Briassoulis, H. (2000). Analysis of land use change. Theoretical and Modelling Approaches.

[2] Subramani, K \& Vishnumsno, J. (2014). Land Use and Land Cover Change Detection and Urban Sprawl. International Journal of Engineering Research and Application, 4(6), 127-217. Retrieved from www.ijera.com.

[3] Okoth, Z. (2012). The Kenya sugar Industry Strategic plan.

[4] Kweyu, W. W. (2013). Factors influencing withdrawal of farmers from sugarcane farmimng.

[5] Rajyashree, S. (2014, November 21). Retrieved December 2014, from The Hindu.

[6] Weda, A. (2015). Illegal sugar, not the imports, is the greatest threat to the local industry. Daily Nation.
[3]Okoth, Z. (2010-2014). The Kenya sugar Industry Strategic plan.

[7] Opanga, K. (2014). State must come to the rescue of cane farmers. Daily Nation. Retrieved from www.nation.co.ke/oped/opinion/state-must come-tothe-resque of cane farmees.

[8] Kennedy, E. (1989). The effects of Sugarcane Production on Food Security, Health, and Nutrion In Kenya. International Food Policy Res Institution.

[9] Bayan, A.; Ahamad, A.\& Ryutaro, T. (2011). Assessment of Land Use/Cover Change and Urban Expansion of the central part of Jaordan using Remte sensing and GIS. Asian Journal Geinformatic, 11(3).

[10] Daynes, W. \& Abi A. (2013). Mumias sugar camapny ( secret to sweet success). Retrieved November 28, 2015, from bus-ex.com/article/mumias-sugar-company.

[11] Noam, H (1990). Tonotopic mapping in auditory cortex of the chinchilla. Hear. Res.100:157-163.

[12] Arum, M. (2013). Sugarcane is one of the most viable crops to grow. Standard newspape. Retrievedfromhtt://www.standardmedia.co.ke/article/20 00096765/sugarcane-is-one-of-the-most-viable-cro to grow?

\section{Author Profile}

Hellen Mbayaki Hellen Mbayaki has a bachelor of degree in surveying technology which she attained in 2013.currently she is pursuing her master"s segree in Geospatail Information System and Remote Sesing at Dedan Kimathi University of technology.she works with the ministry of lands and has fiveteen years experience on Landsurveying and mapping works.

Kenneth Mubea has wide knowledge of Geomatics, GIS and Remote sensing and their applications in numerous fields. He is a Lecturer at DedanKimathi University of Technology, Nyeri, Kenya. He holds a Bachelor"s degree in Geomatic Engineering from Jomo Kenyatta university of Agriculture and technology (Kenya), an MSc degree in GIS and Remote Sensing from Jomo Kenyatta university of Agriculture and technology (Kenya) and a $\mathrm{PhD}$ in Remote Sensing \& GIS from University of Bonn (Germany). He has authored many papers and attended various international conferences. His interests are urban growth modeling, remote sensing, cellular automata, GIS, Land information systems (LIS), surveying, Geodesy, web mapping among other related disciplines in Geomatics

Prof. Charles N. Mundia has Considerable research and teaching experience in Geomatic Engineering, GIS and Remote Sensing analyses of over nine years both locally and internationally. Two year post-doctoral research experience at the school of Integrative Environmental Science, University of Tsukuba., Served as an associate professor of GIS and Remote Sensing for two years at the Centre for Spatial Information Science, University of Tsukuba, Japan..Served as head of department and a senior lecturer at the department of Geomatic Engineering and Geospatial Information Science of Jomo Kenyatta University. Currently an Associate Professor of Geoinformatics at Dedan Kimathi University of Agriculture and Technology, Institute of Geomatic, GIS and Remote Sensing. Authored two University level books published by Nova Science publishers (USA) and Lambert Publishing Company (Germany) and have published widely in high impact international journals on Remote sensing and GIS analyses. Appears in the "Who is Who" in Science and Engineeringe, eleventh edition (2011-2012) by Marquis who is who publication board of United States. 